\title{
LED-BASED LIGHT SOURCES FOR DECONTAMINATION OF FOOD: MODELLING PHOTOSENSITIZATION-BASED INACTIVATION OF PATHOGENIC BACTERIA
}

\author{
Z. Vaitonis and Ž. Lukšienė \\ Institute of Applied Research, Vilnius University, Sauletekio 10, LT-10223 Vilnius, Lithuania \\ E-mail: zivile.luksiene@tmi.vu.lt
}

Received 18 September 2009; revised 22 January 2010; accepted 19 March 2010

\begin{abstract}
The aim of this study was to develop modern light technology (photosensitization) for non-thermal decontamination of different surfaces including food. For this purpose a light emitting diode (LED) based light source was constructed. The highpower LEDs (mfr Seoul Semiconductors) with peak wavelength at $400 \mathrm{~nm}$ were mounted within the prototype of light source. Antimicrobial action of aminolevulinic acid-based photosensitization was evaluated using three pathogenic bacteria (Bacillus, Listeria, and Salmonella) usually distributed on the surface of food. Pathogen inactivation by almost 6-7 orders of magnitude was achieved by ALA-based photosensitization. We suggest mathematical description for kinetics of the bacteria number within inactivation process, which is in good agreement with experimental data. Theoretical analysis of the experimental data helps in revealing the optimal conditions for food decontamination process.
\end{abstract}

Keywords: LED, photosensitization, antimicrobial action

PACS: 85.60.Jb, 87.50.W-, 83.80.Ya

\section{Introduction}

Recently, there has been an increased concern about the microbial safety of the world food. The Center for Disease Control and Prevention (CDC) estimates that 1.4 million cases of salmonellosis and 2.500 cases of listeriosis occur annually in the USA [1]. It is estimated that only listeriosis account for about 200 million $\$$ in monetary loss per year in the USA [2].

The major existing technologies for food decontamination and preservation have various shortages, for example, thermal effects usually inducing different physical and chemical changes in the food matrix which significantly reduce the nutritional value of it. Progress in solid state lighting allows a new application of light emitting diodes (LEDs). LEDs with peak wavelength near UV already are in use for purification of water or disinfection of surfaces [3-7].

LED-based photosensitization is the result of a combined effect of three nontoxic agents: photosensitizer, light, and oxygen. Different microorganisms die after their treatment with appropriate photosensitizer and visible light [8]. This feature of microorganisms looks very attractive, especially from the point of view of decontamination of food or food-related surface.

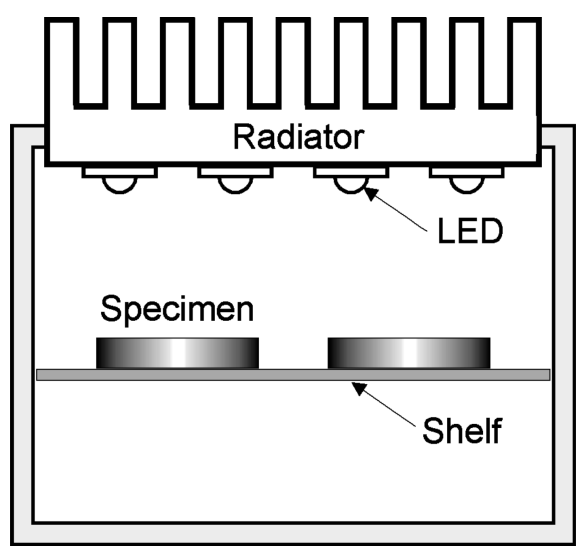

Fig. 1. Structure of the LED-based light source prototype.

\section{Materials}

The prototype of light emitting diodes based light source was constructed in the Institute of Applied Research of Vilnius University. 1 watt electrical power and $410 \mathrm{~nm}$ peak wavelength LEDs (mfr Seoul Semiconductors) were used in the prototype we constructed. LEDs were driven with continuous nominal forward current of $350 \mathrm{~mA}$. The structure of the module is shown in Fig. 1. The LEDs are mounted on radiator and placed inside the metal box. The heat generated by 
LEDs is taken away from the module to prevent thermal effect on food matrix. Cool and stable temperature is very important while green vegetables or fruits are used for inactivation process. Also higher temperature causes better conditions for bacteria fission. Feature of effective heat offtake from the active area makes LEDbased lamps a promising type of light source. The shelf for food matrixes is mounted under LEDs with short distance to guaranty high enough energy of light. The photon flux density of $20 \mathrm{~mW} / \mathrm{cm}^{2}$ was achieved at the surface of samples. Light dose was calculated as light irradiance multiplied by time. Light power density measurements were performed with a light energy meter 3 Sigma Meter (Coherent, Santa Clara, U.S.A.) equipped with piro-electrical detector J25LP04. No thermal changes were detected within the prototype due to good abstraction of heat generated by LEDs. Monitoring of the surface of samples did not show increased temperature also.

Stock solution of aminolevulinic acid (ALA) (Fluka, Rehovot, Israel) was prepared by dissolving ALA in $100 \mathrm{mmol}^{-1}$ phosphate-buffered saline (PBS) (pH 7.2) for photosensitizer as described in [9]. Three types of bacteria were investigated. Bacillus cereus, Listeria monocytogenes, Salmonella enterica were grown and prepared for photosensitization experiments as described in [10]. The experiments were carried out in triplicate for each set of exposure. A standard error was estimated for every experimental point and marked in a figure as an error bar. Sometimes the bars were too small to be visible.

\section{Results}

In our previous studies (Bacillus, Salmonella, Listeria) using fluorimetric analysis of endogenously produced porphyrins it was confirmed that all three pathogens are able to produce endogenous photosensitizers [11].

The data obtained revealed that toxicity of ALA alone (3-7.5 $\mathrm{mmol}^{-1}$ ) without illumination on viability of all three pathogens was as usual negligible. Illumination alone as a rule has no effect on survival of bacteria as well. The incubation of cells with ALA and subsequent illumination (0-20 $\mathrm{min}$ ) decreased the survival fraction fairly sharply (Fig. 2). It is clear that the prolongation of incubation (from 2 to $60 \mathrm{~min}$ ) with $3 \mathrm{mmoll}^{-1}$ ALA increased the rate of bacterial inactivation. As a matter of fact, photosensitization efficiency can be expressed as a function of accumulated

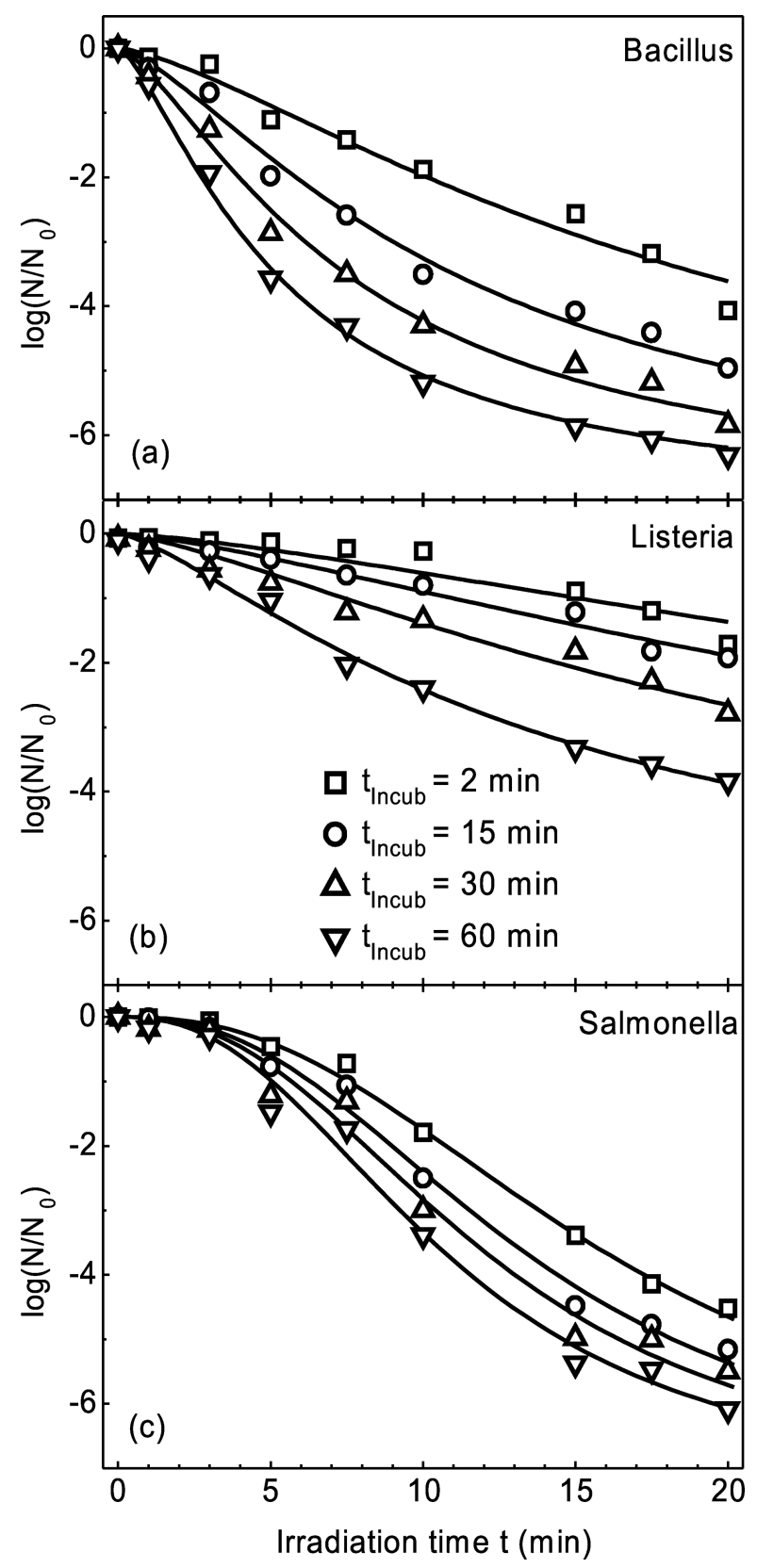

Fig. 2. Kinetics of the relative number of (a) Bacillus, (b) Listeria, and (c) Salmonella after different times of incubation.

photosensitizer multiplied by the total light energy delivered to the bacterial cells.

From data presented in Fig. 2 it is obvious that the dependence of surviving bacteria fraction on irradiation time (energy dose) exhibits nonlinear sigmoidal behaviour. We propose a mathematical model describing microbial inactivation after ALA-based photosensitization. Various functions could be applied for approximation of such inactivation curves [12-15]. Meanwhile, most of them consist of too many parameters, which cannot be described in time dimension. A simple fitting function was selected empirically for the best 
conjunction with experimental data. We propose the function (1) which contains three parameters and two of them have time dimension.

According to this model, the reduction of a relative number of the bacterial population $N$ can be expressed by this equation:

$$
\log \frac{N}{N_{0}}=A\left[1-\frac{1}{1+(t R)^{P}}\right]
$$

where $N_{0}$ and $N$ are an initial number of cells and a number of cells after treatment correspondingly, $A$ is a parameter which describes the number of resistant cells, $t$ is illumination time, $R$ is parameter that describes reduction suddenness of the bacterial population and is in inverse proportion to time ( $R$ can be seen as rate of reduction of relative bacteria number $\left.\log \left(N / N_{0}\right)\right), P$ is parameter that reflects the shoulder on the inactivation curve at initial stage of illumination. The fitting of experimental data points by Eq. (1) is depicted in Fig. 2 (curves).

Experimental data are in agreement with this model and confirm that $40 \mathrm{~min}$ irradiation time is effective enough to destruct all microorganisms (data not shown). After the mentioned irradiation time, the relative number of surviving cells can be expressed as

$$
\log \frac{N}{N_{0}}=A
$$

and does not depend on the irradiation time any more.

The initial population of bacteria consists of the cells resistant to the treatment $\left(N_{\text {resist }}\right)$, the cells which can repair damage and survive ( $\left.N_{\text {repair }}\right)$ after the illumination, and sensitive to the treatment cells due to the absence / loss of repair systems ( $\left.N_{\text {sensit }}\right)$. From the technological point of view the most important is the possibility to reduce the number of $N_{\text {resist }}$ and $N_{\text {repair }}$ bacteria. Some differentiated resistance of pathogens to photosensitization was observed at initial time $t$ (Fig. 2). For instance, the increase of illumination time reduced the survived fraction of Bacillus very sharply, whereas Listeria cells "survived" low doses of treatment and only after 5 min of illumination a more pronounced reduction of survived fraction was observed. It can be explained by the existence of a characteristic time for active agents to damage vital parts of bacteria. We suppose that the characteristic time should not depend on incubation time. To confirm this, weak dependence of parameter $P$ on incubation time was found from the approximation. Therefore, $P$ was set as a global variable for data with different incubation time. This parameter is a characteristic for different bacteria type.

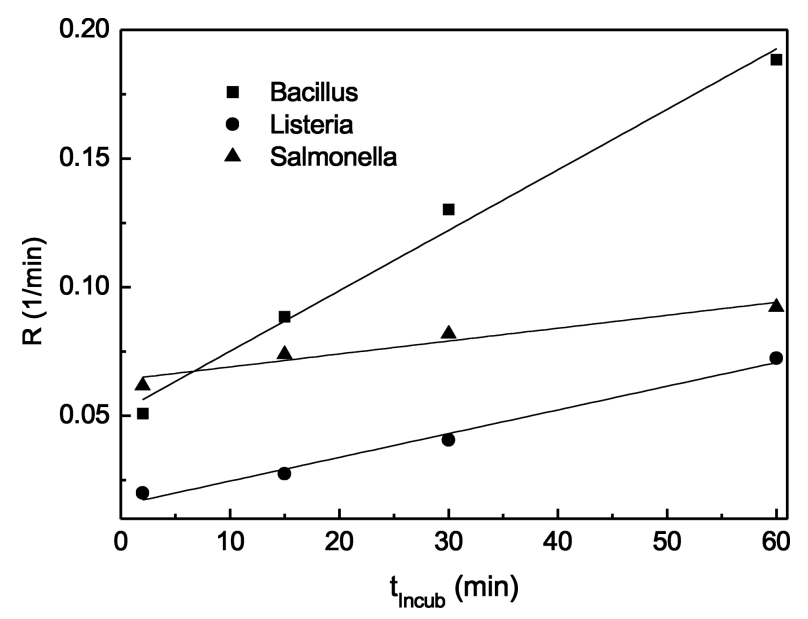

Fig. 3. Dependence of bacterial inactivation rate $R$ on the incubation time.

The surviving fraction (relative bacteria number) starts to decrease rapidly after some characteristic time of initial bacterial resistivity. Kinetics of decrease strongly depends on incubation time. The longer incubation time the steeper reduction of relative number of bacteria was observed due to higher concentration of produced porphyrins. The linear dependence of parameter $R$ on the incubation time is shown in Fig. 3. In the case of Salmonella and partly of Listeria, inactivation rate $R$ has weak dependence on incubation time, which means that there is no point to use long incubation times for these bacteria because inactivation rate $R$ will not increase significantly.

A number of resistant bacteria can remain after a long time of irradiation. These bacteria or descendants of them are insensitive to high-energy light. Parameter A describes a difference in orders between initial number of bacteria and number of bacteria after long time of irradiation that is enough to kill all sensitive bacteria. This parameter is global too, due to independence on incubation time.

\section{Discussion}

Antimicrobial photosensitization-based technique has been developed especially during the last 25 years.

First results obtained on inactivation of different pathogenic bacteria by ALA-based photosensitization seem promising, as antibacterial efficiency of this method seems high in comparison with chemical disinfectants and, according to our investigation, no resistance to this treatment has developed. For instance, Wirtanen et al. evaluated efficacy of common commercial disinfectants (based on hypochlorite, hydrogen peroxide, alcohol, and peracetic acid) against some pathogens and 
Table 1. Parameters of function (1) determined from experimental data.

\begin{tabular}{|c|c|c|c|c|}
\hline & & Bacilus & Listeria & Salmonela \\
\hline & $A$ & -7 & -7 & -7 \\
\hline & $P$ & 1.42 & 1.37 & 2.43 \\
\hline \multirow{4}{*}{$\begin{array}{c}R \\
\min ^{-1}\end{array}$} & $t_{\text {Incub }}=2 \mathrm{~min}$ & 0.05 & 0.02 & 0.06 \\
\hline & $t_{\text {Incub }}=15 \mathrm{~min}$ & 0.09 & 0.03 & 0.07 \\
\hline & $t_{\text {Incub }}=30 \mathrm{~min}$ & 0.13 & 0.04 & 0.08 \\
\hline & $t_{\text {Incub }}=60 \mathrm{~min}$ & 0.19 & 0.07 & 0.09 \\
\hline
\end{tabular}

spoilage microbes in biofilms [16]. It came clear that Gram-positive bacteria tested in poloxamer hydrogels were reduced by $\sim 0.1$ to $\sim 2$ orders of magnitude and Gram-negative bacteria were even more resistant. Furthermore, survived cells are able to grow and recontaminate surfaces. In addition, harmful chemical compounds commonly are unstable, corrosive, and toxic [17].

Theoretical kinetics of the relative number of bacteria can be determined, after all the parameters are found from the approximation of experimental data (Table 1). It allows calculating the irradiation time dependence on incubation time for each reduction of bacteria density. The sets of $t-t_{\text {Incub }}$ dependences can be estimated for every inactivation level. The optimal choice for incubation and illumination must be made corresponding to the importance of one of the process: incubation or irradiation.

Data obtained indicate that the absence of any bacterial resistance to this treatment (what is in line with results of other authors [18]) is one of the most important advantages of photosensitization in comparison with other antibacterial tools.

\section{Conclusions}

The photosensitization-based inactivation of bacteria performed with LED-based light source reveals that the application of high-energy illumination is a promising and efficient method for decontamination of food. The bacteria such as Bacillus, Listeria, and Salmonella are sensitive to photosentization process and inactivation by even 6-7 orders of magnitude was achieved at certain experimental conditions. Our proposed mathematical description for kinetics of the bacteria is in good agreement with experimental data and can be used for optimization of decontamination process.

\section{Acknowledgements}

This study was supported by the EC (FP6, STREP project HighQRTE). Authors thank their students E. Paškevičiūtè and I. Buchovec for their contribution to this work.

\section{References}

[1] T.I. Mbata, Poultry meat pathogens and its control, Internet J. Food Safety 7, 20-28 (2005).

[2] Centers for Disease Control and Prevention (CDC), 2002, Multistate outbreak of listeriosis-United States. MMWR. Morb. Mortal. Wkly. Rep. 51, 950-951.

[3] T. Koutchma, UV light for processing foods, Ozone Sci. Eng. 30, 93-98 (2008).

[4] N. Elmnasser, S. Guillou, F. Leroi, N. Orange, A. Bakhrouf, and M. Federighi, Pulsed-light system as a novel food decontamination technology: a review, Can. J. Microbiol. 53, 813-821 (2007).

[5] Z. Luksiene, V. Gudelis, I. Buchovec, and J. Raudeliuniene, Advanced high-power pulsed light device to decontaminate food from pathogens: effects on Salmonella typhimurium viability in vitro, J. Appl. Microbiol. 103, 1545-1552 (2007).

[6] F. Fine and P. Gervais, Efficiency of pulsed UV light for microbial decontamination of food powders, J. Food Protect. 67, 787-792 (2004).

[7] B.R. Yaun, S.S. Sumner, J.D. Eifert, and J.E. Marcy, Inhibition of pathogens on fresh produce by ultraviolet energy, Int. J. Food Microbiol. 90, 1-8 (2004).

[8] Ž. Lukšienè, New approach to inactivation of harmful and pathogenic microorganisms by photosensitization, Food Technol. Biotechnol. 43, 411-418 (2005).

[9] Ž. Lukšienè, H. Danilčenko, Z. Tarasevičienè, Ž. Anusevičius, A. Marozienė, and H. Nivinskas, New approach to the fungal decontamination of wheat used for wheat sprouts: Effects of aminolevulinic acid, Int. J. Food Microbiol. 116, 153-158 (2007).

[10] Z. Luksiene, I. Buchovec, and E. Paskeviciute, Inactivation of food pathogen Bacillus cereus by photosensitization in vitro and on the surface of packaging material, J. Appl. Microbiol. 107, 2037-2046 (2009).

[11] Y. Le Marc, I. Buchovec, S.M. George, J. Baranyi, and Z. Luksiene, Modelling the photosensitization-based inactivation of Bacillus cereus, J. Appl. Microbiol. 107, 1006-1011 (2009).

[12] R. Vitro, D. Sanz, I. Álvarez, S. Condón, and J. Raso, Application of the Weibull model to describe inactivation of Listeria monocytogenes and Escherichia coli by citric and lactic acid at different temperatures, J. Sci. Food Agr. 86, 865-870 (2006).

[13] R.J.W. Lambert, A model for the thermal inactivation of micro-organisms, J. Appl. Microbiol. 95, 500-507 (2003). 
[14] O. Erkmen, Mathematical modeling of Saccharomyces cerevisiae inactivation under high-pressure carbon dioxide, Nahrung / Food 47, 176-180 (2003).

[15] D.L. Holcomb, M.A. Smith, G.O. Ware, Y.-C. Hung, R.E. Brackett, and M.P. Doyle, Comparison of six doseresponse models for use with food-borne pathogens, Risk Anal. 19, 1091-1099 (1999).

[16] G. Wirtanen, M. Aalto, P. Härkönen, P. Gilbert, and T. Mattila-Sandholm, Efficacy testing of commercial disinfectants against foodborne pathogenic and spoilage microbes in biofilm-constructs, Eur. Food Res. Technol. 213, 409-411 (2001).

[17] G. Wirtanen and S. Salo, Disinfection in food processing - efficacy testing of disinfectants, Rev. Environ. Sci. Biotechnol. 2, 293-306 (2003).

[18] Y. Nitzan and H. Ashkenazi, Photoinactivation of Acinetobacter baumannii and Escherichia coli B by a cationic hydrophilic porphyrin at various light wavelengths, Curr. Microbiol. 42, 408-414 (2001).

\title{
ŠVIESTUKAI PRIEŠ MAISTO UŽKRATUS: BAKTERIJŲ NAIKINIMO ŠVIESA MODELIAVIMAS
}

\author{
Z. Vaitonis, Ž. Lukšienè \\ Vilniaus universiteto Taikomuju mokslu institutas, Vilnius, Lietuva
}

\section{Santrauka}

Siekiama sukurti šiuolaikišką šviesos technologiją (fotosensibilizaciją), kurią galima panaudoti neterminiam maisto apdorojimui. Šiam darbui buvo pagamintas prototipas su puslaidininkiniais didelès galios šviesos diodais, kurių spinduliuojamos bangos ilgis yra $400 \mathrm{~nm}$. Tyrimas atliktas naudojant tris bakteriju rūšis: Bacillus cereus, Listeria monocytogenes, Salmonella enterica. Naudojant ši kietakūnį šviesos šaltini, pasiekta beveik 100\% bakterijų žūtis. Eksperimentų rezultatų analizei pasiūlème matematini bakterijų skaičiaus kinetikos aprašymą, kuris galètu padèti optimizuoti dezinfekcijos procesą. 